\title{
Potential Toxic Heavy Metal Contamination of Roadside Soil
}

\author{
Pankaj Kumar* and Kuldeep \\ Department of Soil Science \\ CCS Haryana Agricultural University, Hisar-125004, India
}

*Corresponding author

\section{A B S T R A C T}

\begin{tabular}{|l|}
\hline K e y w or d s \\
Traffic, Roadside, \\
$\begin{array}{l}\text { Contamination, } \\
\text { Heavy metal }\end{array}$ \\
\hline Article Info \\
\hline $\begin{array}{l}\text { Accepted: } \\
\text { 06 June } 2018 \\
\text { Available Online: } \\
\text { 10 July } 2018\end{array}$ \\
\hline
\end{tabular}

\section{Introduction}

Heavy metal concentration in agricultural soils can affect human beings directly, through soil ingestion or through the food web by ingestion of crops and animals. Indirectly it causes severe damage of environmental health. The levels of metals in all environments, including air, water and soil are increasing in some cases to toxic levels, with contributions from wide variety of industrial and domestic sources. Metal contaminated environments pose serious threat to health and ecosystems. Metals like arsenic, cadmium, lead; mercury, silver etc cause conditions including hypophosphatemia, heart disease and liver damage, cancer and neurological and cardiovascular diseases, central nervous system damage and sensory disturbances. Atmospheric deposition of heavy metal, urban-industrial activities and agricultural practices by using agrochemical products are the main anthropic sources of heavy metals in agricultural soils.

The metals are classified as "heavy metals" if, in their standard state, they have a specific gravity of more than $5 \mathrm{~g} / \mathrm{cm}^{3}$. There are sixty known heavy metals. Heavy metals can accumulate over time in soils and plants and could have a negative influence on physiological activities of plants (e.g. 
photosynthesis, gaseous exchange, and nutrient absorption), causing reductions in plant growth, dry matter accumulation and yield (Devkota and Schmidt, 2000). The heavy metals contamination in soils from automobile sources is a serious environmental issue. These metals are released during different operations of the road transport such as combustion, component wear, fluid leakage and corrosion of metals. Lead, cadmium, copper, and zinc are the major metal pollutants of the roadside environments and are released from fuel burning, wear out of tyres, leakage of oils, and corrosion of batteries and metallic parts such as radiators etc. (Dolan et al., 2006).

\section{Contamination of roadside soil}

Soils near the roads, industrial area, mines act as a sink for heavy metal. Mean concentrations of $\mathrm{Cu}, \mathrm{Fe}, \mathrm{Pb}, \mathrm{As}, \mathrm{Mn}, \mathrm{Zn}, \mathrm{Cd}$ and $\mathrm{Ni}$ were significantly higher near heavy traffic areas and the industrial area than other sampling areas followed an increasing trend with the increase in depth. The vertical movement of all the metals, exhibited predominant association with soil $\mathrm{pH}$ and organic carbon. The concentration of the heavy metals suggests that automobiles and traffic activities are a major source of these metals in the roadside soil within the study area (Akan et al., 2013). Radmila et al., 2013 opined that total concentrations of $\mathrm{Ni}$ above the maximum allowable concentration were analysed in $8.3 \%$ of all samples and are equally spread out along the area of research. Extreme concentration of this element (over $200 \mathrm{mg} . \mathrm{kg}^{-1}$ ) was registered in $0.8 \%$ of the samples in the zone at $10 \mathrm{~m}$ distance from the roadside. Similarly in case of $\mathrm{Pb}$ the concentrations of $\mathrm{Pb}$ above the maximum allowable concentration were recorded in $28.5 \%$ of the samples, except one sample that registered an extremely high concentration of this element of $215.45 \mathrm{mg}$. $\mathrm{kg}^{-1}$, and the position of the sample was from an area $10 \mathrm{~m}$ from the road.

A chemical fractionation was studied in soil taken from road sides. It was found that less than $1 \% \mathrm{~Pb}$ and below $5.5 \% \mathrm{Zn}$ were in exchangeable therefore, $\mathrm{Pb}$ and $\mathrm{Zn}$ are predominantly present in non-exchangeable forms in the studied soils. These nonexchangeable metals were associated with different soils materials. $\mathrm{Pb}$ was mainly associated with the organic fraction, as well as to the inorganic and residual fractions, and $\mathrm{Zn}$ was found associated to the inorganic and residual fractions, and also to the iron oxides, being practically absent in the organic fraction. (Miragaya et al.1980)

Miragaya (1980) investigated the level, chemical fractions, and solubility of $\mathrm{Pb}$ in 25 roadside soil samples taken from heavily traveled areas of Caracas, Venezuela and found a very high level of $\mathrm{Pb}$ (average enrichment factor 21.0). This high level of $\mathrm{Pb}$ indicating a strong lead pollution in roadside soils by heavy traffic of motor vehicles. Lead was present in nonexchangeable forms, less than $0.7 \% \mathrm{~Pb}$ was in exchangeable form in these soils. Nonexchangeable $\mathrm{Pb}$ was found associated mainly with the organic and residual fractions in two out of the three soils and in inorganic sites in the third soil.

A selective sequential extraction procedure was conducted for the chemical fractionation of cadmium, copper, nickel, and zinc in contaminated soils by Lena and Rao (1997). The most abundant pool for all four metals examined was the residual fraction. A significant amount of $\mathrm{Zn}(2.4-44 \%)$ was present in the potentially available in non residual fraction. A major portion (40-74\%) of $\mathrm{Cu}$ was associated with the organic, Fe-Mn oxide, and carbonate fractions in most of the soils. The contamination of $\mathrm{Zn}$ and $\mathrm{Cu}$ is more severe as compared to $\mathrm{Cd}$ and $\mathrm{Ni}$ in 
these soils. Assuming that mobility and bioavailability of these heavy metals are related to their solubility and geochemical forms, and that they decrease in the order of extraction sequence, the apparent mobility and potential bioavailability for these four metals in the soils were: $\mathrm{Zn}>\mathrm{Cu}>\mathrm{Cd}>\mathrm{Ni}$.

Norrstrom and Jacks (1998) did a study on heavy metal contamination along two lines of a highway, $0.5 \mathrm{~m}$ and $2.5 \mathrm{~m}$ from the asphalt surface and in an infiltration pond for highway runoff. The level of $\mathrm{Cd}, \mathrm{Pb}$ and $\mathrm{Zn}$ in soil samples from the highway $(0.5 \mathrm{~m})$ and in the infiltration pond exceeded guideline values for less sensitive land-use with groundwater protection. The highest $\mathrm{Pb}$ concentration measured (542 $\mathrm{mg} \mathrm{kg}^{-1}$ ) was 34 times the average $\mathrm{Pb}$ concentration in soils in Sweden, and exceeded the Swedish guideline value by a factor of almost two. Cadmium in the infiltration pond exceeded the guideline value almost three times. An increased concentration with soil depth for $\mathrm{Cd}, \mathrm{Pb}, \mathrm{Cu}, \mathrm{Zn}$ and PAHs in the infiltration pond showed that downward transport had occurred. This was supported by a $\mathrm{Pb}$ concentration exceeding the limit for drinking water quality in the groundwater 4.5 $\mathrm{m}$ below the soil surface in the infiltration pond.

The increasing industrialization particularly due to oil exploration and exploitation in the Niger Delta region of Nigeria has created a lot of damages to the environment. A study of metal concentration near Warri refinery found three to seven times elevated level of various heavy metals in the soil (Ndi Kwere and Revenue, 2000). According to Atolaiye et al., (2006) contamination of heavy metals in the environment has adverse effect on soil chemical composition; this has been a major concern because of their toxicity and threat to human life and the environment.

Olajire et al., (2002) did a case study on levels and speciation of heavy metals in soils of industrial southern Nigeria and observed the fraction of heavy metal:- water soluble, exchangeable, carbonates, Fe-Mn oxide, organic and residual. Metal concentration obtained were within $\pm 10 \%$ of the independently determined total $\mathrm{Cd}, \mathrm{Pb}, \mathrm{Cu}, \mathrm{Ni}$ and $\mathrm{Zn}$ concentrations. The highest amount of $\mathrm{Cd}$ (avg. 30\%) in the non-residual fractions, while $\mathrm{Zn}$ and $\mathrm{Cu}$ were significantly associated with the organic fraction. The carbonate fraction obtained on average 14, 18.6, 12.6, 13 and $11 \%$ and the residual fraction obtained on average $47,18,33,50$ and $25 \%$ of $\mathrm{Cd}, \mathrm{Pb}, \mathrm{Cu}$, $\mathrm{Ni}$ and $\mathrm{Zn}$ respectively. The mobility indexes of $\mathrm{Cu}$ and $\mathrm{Ni}$ correlated positively and significantly with the total content of these metals, while mobility indexes of $\mathrm{Cd}$ and $\mathrm{Zn}$ correlated negatively and significantly with the total content of these two metals.

Hjortenkrans et al., (2005) divided the studied heavy metals into three groups according to different emission sources: metals as historical residues from the combustion of petrol $(\mathrm{Pb}$ and $\mathrm{Cd}$ ), metals from decelerating activities $(\mathrm{Cu}, \mathrm{Sb}$ and $\mathrm{Zn})$, and non-source-specific metals $(\mathrm{Cr}$ and $\mathrm{Ni})$. It was observed that $\mathrm{Cu}$ and $\mathrm{Sb}$, despite their short history as trafficemitted metals, have increased more than eightfold in roadside soils compared to background levels. The main source of road traffic related $\mathrm{Cu}$ and $\mathrm{Sb}$ is brake linings. The significant increase of $\mathrm{Cu}$ and $\mathrm{Sb}$ in roadside topsoil shows the need for metal transport studies.

Akbar et al., (2006) conducted a study on heavy metal contamination in roadside soils of northern England and analyzed their concentrations and distributions in different road verge zones (border, verge, slope, ditch). Lead concentration was the highest in the soil among $\mathrm{Pb}, \mathrm{Zn}, \mathrm{Cd}, \mathrm{Cu}$ and cadmium was the lowest. Though the levels of heavy metals in roadside soils were higher as compared to their natural background levels in British soils, their concentrations in general, however, were 
below the 'critical trigger concentrations' for the contaminated soils. The border zone had the highest mean concentration of the four metals whereas the ditch zone exhibited the lowest mean concentration.

Lokeshwari and Chandrappa (2006) did a study in and around the city of Bangalore, where they assessed the heavy metal contamination of vegetation and soil due to irrigation with sewage-fed lake water on the agricultural land. The results showed significant amount of heavy metals, above the Indian Standard limits in both the soil as well as the vegetation samples. Krishna and Govil (2007) while studying the soil contamination due to heavy metals from an industrial area of Surat, Gujarat, Western India reported that soils in the vicinity of Surat industrial area were found to be significantly contaminated with metals like $\mathrm{Cu}, \mathrm{Cr}, \mathrm{Co}, \mathrm{V}$ and $\mathrm{Zn}$ at levels far above the background concentration in soil, which may give rise to various health hazards.

The mechanic waste dumps are potential sources of heavy metal pollution to soil. A study was conducted on heavy metal contamination by Iwegbue et al., (2006) in mechanic waste dumpsites. The results of study show that the concentration of heavy metals $(\mathrm{Cd}, \mathrm{Cr}, \mathrm{Cu}, \mathrm{Pb}, \mathrm{Ni}$ and $\mathrm{Zn})$ decreased with the depth of the profile. The results also show that heavy metals concentration also decrease in lateral distance from the dumpsites. The concentration of heavy metals exceeded background concentrations and limits for agricultural and residential purposes. The pattern of heavy metals concentration in the soil profiles were in the following sequence $\mathrm{Pb}>\mathrm{Zn}>\mathrm{Cu}>\mathrm{Cd}>\mathrm{Ni}$ $>\mathrm{Cr}$. The high level of heavy metals in these soil profiles is a serious threat to both surface and groundwater.

A research work was conducted to study of soil and water samples obtained from four sampling points; around an oil well head, flare site, waste pit and effluent discharge point in an exploration area in the Niger Delta were analysed for their heavy metals contents. Results showed that the amount of lead present in the soil ranges from $3.40-99.40$ $\mathrm{mg} / \mathrm{kg}$, copper values were in the range of $5.10-49.30 \mathrm{mg} / \mathrm{kg}$, Nickel concentration vary from $1.60-13.80 \mathrm{mg} / \mathrm{kg}$, values for cadmium, iron, zinc, and chromium were 0.04 - $0.95 \mathrm{mg} / \mathrm{kg}, 536.00-12,872.00 \mathrm{mg} / \mathrm{kg}$, $11.1-274.00 \mathrm{mg} / \mathrm{kg}$ and $1.30-165.00 \mathrm{mg} / \mathrm{kg}$ respectively. Apart from zinc and nickel, all other heavy metals were higher than the toxicity limits for heavy metals in natural soil; this implies pollution of the soil by heavy metals. Also the waters were found to be polluted by lead, the $\mathrm{pH}$ of the water samples was found to deviate significantly from DPR limits and W.H.O. standard for potable water (Asia et al., 2007).

High contents heavy metals could be attributed to anthropogenic effects related to traffic sources. Toxicity characteristics leaching procedure (TCLP) test results reveal that the contaminated soils may be hazardous. Saeedi et al., (2008) studied the contents and leaching characteristics of heavy metals under stable weather conditions in the northern and southern sides of Tehran-Karaj Highway, Iran. The results showed that all heavy metal contents except $\mathrm{Cr}$, $\mathrm{Mn}$ and $\mathrm{Co}$ are higher than acceptable values in natural soils and there is a significant positive correlation between heavy metals and organic matter. Also a significant correlation was observed between $\mathrm{Cd}, \mathrm{Pb}$ and $\mathrm{Zn}$.

Nganje et al., (2010) studied the influence of base metal mining on heavy metal levels in soils and plants in the vicinity of Arufu leadzinc mine, Nigeria and reported that levels of $\mathrm{Zn}, \mathrm{Pb}$ and $\mathrm{Cd}$ in cultivated soils were higher than the concentrations obtained from the control site. They concluded that these heavy metals were most probably sourced from 
mining and agricultural activities in the study area. Parth et al., (2011) while investigating geo-environmental evaluation of heavy metals in/and around hazardous waste disposal sites located in the north-western part of Hyderabad reported that the average concentrations of $\mathrm{As}, \mathrm{Cr}, \mathrm{Pb}$ was found to exceed the threshold and natural background values, whereas the upmost concentrations of $\mathrm{Cu}, \mathrm{Ni}$ and $\mathrm{Zn}$ exceeded the prescribed threshold limit. They further observed that soil $\mathrm{pH}$ significantly affects the solubility and mobility of these metals.

Kluge and Wessolek (2011) studied the accumulation of the heavy metals $\mathrm{Pb}, \mathrm{Cd}, \mathrm{Cu}$ and $\mathrm{Zn}$ in soils samples taken along the oldest federal highway of the world. The results show that concentrations of heavy metals are up to 20 times increased compared to the geochemical background levels and a reference site of $800-\mathrm{m}$ distance from the roadside. Heavy metals concentrations in the topsoil $(0-10 \mathrm{~cm})$ mostly exceeded than the precautionary values of the German Federal Soil Protection and Contamination Ordinance.

An attempt was made by Dasaram et al., (2011) to study toxic metals such as $\mathrm{Cr}, \mathrm{Cu}$, $\mathrm{Ni}, \mathrm{Pb}, \mathrm{Zn}$, including $\mathrm{Ba}, \mathrm{Co}$ and $\mathrm{V}$ in soil samples from Patancheru industrial area near Hyderabad, Andhra Pradesh. It is the most contaminated regions where about 260 small and large-scale manufacturers of pharmaceuticals, pesticides, paints, chemicals, steel and metallic products industries have been functioning for over several decades. Toxic heavy metal geochemical studies were carried out in fifteen representative soil samples collected from agricultural and residential area, to understand the spatial distribution and to assess the level of contamination on the basis of index of geo accumulation, enrichment factor, and degree of contamination. Result show that residential soil was contaminated with $\mathrm{Cr}, \mathrm{Ni}$ and $\mathrm{Pb}(\mathrm{Cu}$ to some extent). The agricultural areas were invariably enriched in these heavy metals, showed comparatively less contamination possibly due to uptake by plants.

A study on quality of soil with reference to $\mathrm{Zn}, \mathrm{Pb}, \mathrm{Fe}, \mathrm{Mn}$ and organic carbon in the soils of Eastern Guwahati Industrial zone, Assam was carried out by Deka and Sarma (2012). They revealed that the top soils in the area were heavily polluted with heavy metals and resulting coefficient of correlation between heavy metals and soil properties established a nonlinear relationship between the parameters.

\section{References}

Adamu, C.I. and Nganje, T.N., 2010. Heavy metal contamination of surface soil in relationship to land use patterns: a case study of Benue State, Nigeria. Materials Sciences and Applications, 1(03): 127.

Akan, J.C., Audu, S.I., Audu, Z.M. and Ogugbuaja, V.O., 2013. Assessment of heavy metals, $\mathrm{pH}$, organic matter and organic carbon in roadside soils in Makurdi metropolis, Benue state, Nigeria. Journal of Environmental Protection, 4(06): 618.

Akbar, K.F., Hale, W.H., Headley, A.D. and Athar, M., 2006. Heavy metal contamination of roadside soils of Northern England. Soil Water Res, 1(4): 158-163.

Atolaye, B.O., Aremu, M.O., Shagye, D. and Pennap, G.R., 2006. Distribution and concentration of some mineral elements in soil sediment, ambient water and the body parts of Clarias gariepinus and Tilapia quineensis fishes in river Tammah, Nasarawa state, Nigeria. Current World Environment, 1(2): 95-100.

Dasaram, B., Satyanarayanan, M., Sudarshan, 
V. and Krishna, A.K., 2011. Assessment of soil contamination in Patancheru industrial area, Hyderabad, Andhra Pradesh, India. Research Journal of Environmental and Earth Sciences, 3(3): 214-220.

Deka, J. and Sarma, H.P., 2012. Heavy metal contamination in soil in an industrial zone and its relation with some soil properties. Scholars Research Library. Archives of Applied Science Research, 4(2): 831-836.

Devkota, B. and Schmidt, G.H., 2000. Accumulation of heavy metals in food plants and grasshoppers from the Taigetos Mountains, Greece. Agriculture, ecosystems and environment, 78(1): 85-91.

Dolan, L.M., Bohemen, H., Whelan, P., Akbar, K.F., O'MALLEY, V., O'LEARY, G. and Keizer, P.J., 2006. Towards the sustainable development of modern road ecosystems. In The ecology of transportation: managing mobility for the environment (pp. 275331). Springer Netherlands.

Hjortenkrans, D.S., Bergbäck, B.G. and Häggerud, A.V., 2007. Metal emissions from brake linings and tires: case studies of Stockholm, Sweden 1995/1998 and 2005. Environmental Science and Technology, 41(15): 5224-5230.

Idzi, A.A., Saleh, S.A., Paul, I. and Shekwonyadu, I., Chemical Composition Analysis Of Soil From Selected Oil Producing Communities In The Niger Delta Region Of Nigeria. Iwegbue, C.A., Isirimah, N.O., Igwe, C. and Williams, E.S., 2006. Characteristic levels of heavy metals in soil profiles of automobile mechanic waste dumps in Nigeria. Environmentalist, 26(2): 123-128.

Ize-Iyamu, O.K. and Bernard, A.E., 2007. The effects of petroleum exploration and production operations on the heavy metals contents of soil and groundwater in the Niger Delta. International Journal of Physical Sciences, 2(10): 271-275.

Kluge, B. and Wessolek, G., 2012. Heavy metal pattern and solute concentration in soils along the oldest highway of the world-the AVUS Autobahn. Environmental Monitoring and Assessment, 184(11): 6469-6481.

Krishna, A.K. and Govil, P.K., 2007. Soil contamination due to heavy metals from an industrial area of Surat, Gujarat, Western India. Environmental monitoring and assessment, 124(1- 3): 263-275.

Lokeshwari, H. and Chandrappa, G.T., 2006. Heavy Metals Content in Water, Water Hyacinth and Sediments of Lalbagh Tank, Bangalore (India). Journal of Environmental Science and Engineering, 48(3): 183-188.

Ma, L.Q. and Rao, G.N., 1997. Chemical fractionation of cadmium, copper, nickel, and zinc in contaminated soils. Journal of Environmental Quality, 26(1): 259-264.

Miragaya, J.G., 1980. Specific sorption of trace amounts of cadmium by soils. Communications in Soil Science and Plant Analysis, 11(12): 1157-1166.

Norrström, A.C. and Jacks, G., 1998. Concentration and fractionation of heavy metals in roadside soils receiving de-icing salts. Science of the Total Environment, 218(2-3): 161174.

Olajire, A.A., Ayodele, E.T., Oyedirdan, G.O. and Oluyemi, E.A., 2003. Levels and speciation of heavy metals in soils of industrial southern Nigeria. Environmental Monitoring and Assessment, 85(2): 135-155.

Parth, V., Murthy, N.N. and Saxena, P.R., 2011. Assessment of heavy metal 
contamination in soil around hazardous waste disposal sites in Hyderabad city (India): natural and anthropogenic implications. Journal of Environmental research and management, 2(2): 027-034.

Pivić, R.N., Sebić, A.B.S. and Jošić, D.L., 2013. Assessment of Soil and Plant Contamination by Select Heavy Metals Along a Major European
Highway. Polish Journal of Environmental Studies, 22(5).

Saeedi, M., Hosseinzadeh, M., Jamshidi, A. and Pajooheshfar, S.P., 2009. Assessment of heavy metals contamination and leaching characteristics in highway side soils, Iran. Environmental monitoring and assessment, 151(1-4): 231-241.

\section{How to cite this article:}

Pankaj Kumar and Kuldeep. 2018. Potential Toxic Heavy Metal Contamination of Roadside Soil. Int.J.Curr.Microbiol.App.Sci. 7(07): 465-471.

doi: https://doi.org/10.20546/ijcmas.2018.707.056 